\title{
Re-envisioning Tangintebu Theological College in the context of climate change: An emerging model of coconut theological education and ministerial formation
}

\begin{tabular}{|c|c|}
\hline \multicolumn{2}{|c|}{ 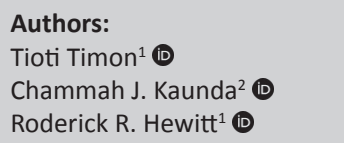 } \\
\hline \multicolumn{2}{|c|}{$\begin{array}{l}\text { Affiliations: } \\
\text { 'School of Religion, } \\
\text { Philosophy and Classics, } \\
\text { University of KwaZulu-Natal, } \\
\text { Pietermaritzburg, } \\
\text { South Africa }\end{array}$} \\
\hline \multicolumn{2}{|c|}{$\begin{array}{l}{ }^{2} \text { United Graduate School of } \\
\text { Theology, Yonsei University, } \\
\text { Seoul, South Korea }\end{array}$} \\
\hline \multicolumn{2}{|c|}{$\begin{array}{l}\text { Corresponding author: } \\
\text { Chammah Kaunda, } \\
\text { pastorchammah@gmail.com }\end{array}$} \\
\hline \multicolumn{2}{|c|}{$\begin{array}{l}\text { Dates: } \\
\text { Received: } 25 \text { June } 2018 \\
\text { Accepted: } 02 \text { Oct. } 2018 \\
\text { Published: } 25 \text { Mar. } 2019\end{array}$} \\
\hline \multicolumn{2}{|c|}{$\begin{array}{l}\text { How to cite this article: } \\
\text { Timon, T., Kaunda, C.J. \& } \\
\text { Hewitt, R.R., 2019, } \\
\text { 'Re-envisioning Tangintebu } \\
\text { Theological College in the } \\
\text { context of climate change: } \\
\text { An emerging model of } \\
\text { coconut theological } \\
\text { education and ministerial } \\
\text { formation', HTS Teologiese } \\
\text { Studies/Theological Studies } \\
75(1), \text { a5169. https://doi. } \\
\text { org/10.4102/hts.v75i1.5169 }\end{array}$} \\
\hline \multicolumn{2}{|c|}{$\begin{array}{l}\text { Copyright: } \\
\text { (c) 2019. The Authors. } \\
\text { Licensee: AOSIS. This work } \\
\text { is licensed under the } \\
\text { Creative Commons } \\
\text { Attribution License. }\end{array}$} \\
\hline \multicolumn{2}{|l|}{ Read online: } \\
\hline 口我回 & $\begin{array}{l}\text { Scan this QR } \\
\text { code with your } \\
\text { smart phone or } \\
\text { mobile device } \\
\text { to read online. }\end{array}$ \\
\hline
\end{tabular}

Authors:

Tioti Timon ${ }^{1}$

Chammah J. Kau

Affiliations:

${ }^{1}$ School of Religion,

Philosophy and Classics,

University of KwaZulu-Natal,

Pietermaritzburg,

${ }^{2}$ United Graduate School of Theology, Yonsei University,

Corresponding author:

Chammah Kaunda,

Dates:

Accepted: 02 Oct. 2018

How to cite this article:

Timon, T., Kaunda, C.J. \&

Hewitt, R.R., 2019,

Re-envisioning Tangintebu

context of climate change:

An emerging model of

coconut theological

education and ministeria

(ution', HTS Teologiese

75(1), a5169. https://doi.

org/10.4102/hts.v75i1.5169

Copyright:

Licensee: AOSIS. This work

is licensed under the

Creative Commons

Attribution License.

mobile device
to read online.
This article engages through an interdisciplinary approach to re-envision Tangintebu Theological College's (TTC) model of theological education in the context of climate change in Kiribati. It utilises the anthropological theory of symbolic interactionism within missiological, cultural and, theological studies of climate change. It argues for the coconut tree as an appropriate cultural conceptual metaphorical idiom for translating and understanding Christian faith and shaping a theological pedagogy within the Kiribati context of climate change. The coconut image is an indigenous, holistic way of knowing and learning informed by Kiribati cosmology embedded within people's experiences and understanding of the coconut tree. Its life-centeredness has the potential to contextualise the theological curriculum and teaching methodology to assist in equipping theological students with climate changesensitive approaches. The qualitative method was utilised to allow participants to reflect on their experiences of climate change in relation to the mission of the church. The data that informs this article was generated through unstructured interviews and focus group discussions with members of the Kiribati Uniting Church (KUC). The data was analysed using symbolic interactionism. The results suggest that the Kiribati people symbolically interact with God through their understanding of the coconut tree, which is conceived as the embodiment of God's presence. It became clear that while this world view informs the faith of members of the KUC, the TTC curriculum has sidelined it, resulting in miseducation of pastors because this omission means they are not equipped to engage with the challenge of climate change. The participants argued that there is an urgent need to understand theological education and ministerial formation within the indigenous framework of Kiribati coconut imagination that is embedded in the promotion of justice and equitable society not only for human beings but for all of God's creation through symbolic interaction with the presence of God in the coconut.

\section{Introduction}

The life-threatening phenomenon of climate change has triggered an urgent search for Pacific theological response among Pacific theologians (Havea 1987; Forman 2005; Palu 2012; Thaman 1990; Tielu 2016; Timon 2013). The quest for an indigenous Pacific theological response started at the Consultation of Pacific Theologians in Papua New Guinea in 1986, where Sione Amanaki Havea (1987) of Tonga called for directing the theological enterprise toward the realities of Pacific contextual challenges. As a result, several Pacific theologians began to think in terms of God and Christianity as a Pacific God and a Pacific Christianity, and to connect this idea to the traditional knowledge systems of islander beliefs and cultures.

Building on this theological tradition, this study employs the symbolic interaction to demonstrate how the Kiribati people conceptualise the presence of God as embodied within the coconut tree. The article argues that Kiribati people tend to define, construct and make meaning of their experiences of God partly through their daily interactions with coconut trees. The coconut tree is conceived of as an embodiment of the divine source of all life and being in the Kiribati context. The people cannot continue to exist on the island without the coconut. Hence, it is entrenched within their world view as a source of life and foundation of existential knowledge. The coconut tree is a symbol of both life and God to the islanders of the Pacific as it embodies the culture and cycle of life that shapes the environment of the people (Palu 2012; Tenten 1994; Uriam 1999). This tree is of more value than any other plant in Kiribati because it produces all of the key elements of 
life and thus the life of the people is constructed around the coconut tree (Thaman 1990; Timon 2013; Havea 1987). Some Pacific scholars have argued that this coconut tree not only sums up the culture of life but discloses the knowledge of who God is and what God has done in and for the land and people of the Pacific (Havea 1987; Palu 2012; Uriam 1999). In agreement with these scholars, Forman stresses, 'in many ways the coconut could symbolize Christ, because it gives life to human beings, and when it is broken new life springs forth' (Forman 2005:116). It makes sense for Pacific scholars to interpret the gospel in their Pacific context rather than the original Western one brought by the missionaries and therefore for Christ to be perceived as a Pacific islander.

According to Bird (2016), human life finds its meaning and explores its true potential within the totality of life in the land as the household of life. In Kiribati, God is seen as the living and life-giving presence who sustains life in the land through coconuts. The coconut image as model for theological education and ministerial formation, as understood in Kiribati, has the potential to epistemologically and pedagogically equip future church leaders to effectively respond to climate change and environmental issues. Tielu (2016) argues that through coconut imagination it is recognised that God speaks to Pacific peoples through the world in which they live and delegates human beings to look after the entire creation (Gn 2:14-15). Hence, Christians must focus more on understanding how God is present in creation within particular local contexts rather than focusing only on theological themes such as sin and redemption (Conradie 2009:42-43). This means giving serious attention to addressing wider environmental concerns by developing a vision of justice and equality concealed within local traditions.

The foregoing raises the question of how the Kiribati Uniting Church (KUC) could revise and transform the theological education at Tangintebu Theological College (TTC) to make it more effective and relevant in the context of climate change in Kiribati. The contemporary model of theological education is shaped by the material legacy of Western missionaries' theological imaginations. The Western classical theological education and theology is not adequate to deal with the ecoproblems surrounding the Kiribati environment. There is a need for a new model of theological education that is informed by both contemporary eco-challenges and indigenous imaginations. The coconut tree within the Kiribati world view has the potential to be a resource that could help in equipping theological students for the challenges of climate change. The question could be raised here: in what ways can the notion of coconut imagination help re-envision theological education that equips ministerial formation for a just and equitable society in the context of climate change? Following this question, this article responds by engaging the data collected from fieldwork with members of the KUC to demonstrate how the local people perceive coconut theological praxis as relevant in equipping the theological student to respond adequately to climate change. It is on this basis that a qualitative engagement was made through the coconut imagination to demonstrate how the KUC, through its theological education and ministerial formation, could respond adequately to climate change threatening the lives of the islanders.

\section{Methodological approach}

The study employed the qualitative method to understand issues affecting the lives of the people. Data was gathered on the quality of theological education used to equip ministerial students of the KUC and then analysed to determine the ways in which the quality of education can be improved to be better equip to them to respond to the challenges of climate change in Kiribati. Open-ended questions were used during the interviews to give 'freedom of expression and allow the respondents to qualify their responses' (Walliman 2011:98). Information-gathering procedures followed faceto-face interviews and focus group discussions with key informants that included theological students, lecturers, local pastors, lay leaders and members of the KUC. The total number of participants, who included youth, men and women, was 54. Secondary data was also collected from church documents, minutes and other relevant information. The supplemental searches also consulted books and journals from the Pacific Theological College library, University of the South Pacific library and University of KwaZulu-Natal library and online sources relevant to the study. The qualitative nature of the study helped to demonstrate that the coconut as theological resource embedded within Kiribati and the wider Pacific region is critical in re-envisioning theological education and ministerial formation adequate to respond to contemporary issues affecting the lives of the people and their islands.

\section{The nation of Kiribati}

Kiribati constitutes one of the nations in the Pacific region. The Kiribati people live on low-lying atolls, with the highest point being $3 \mathrm{~m}$ above sea level - the most vulnerable nation on Earth to cope with rising sea levels. Kiribati is a group of 33 scattered low-lying atolls, 'dispersed in the central Pacific covering an area of over 3.5 million sq.km (1.4 million square miles)' (Thomas 2002:164). Kiribati has a population of 101998 people (Kiribati National Statistic Office 2016) against the land mass estimated at $811 \mathrm{~km}^{2}$ (Collins 2012:31). When considering climate change matters, the important point is that, except for Banaba, all the islands are low-lying coral atolls, no more than $3 \mathrm{~m}$ above sea level. This means lack of height can be a problem when facing rising sea levels (Loughry \& McAdam 2008). Scholars are in agreement that Kiribati, like other low-lying atoll islands, is at high risk as a result of global warming that is causing sea-level rise (Biribo \& Woodroffe 2013; Collins 2012; Donner \& Webber 2014; Gittins 1999). In consequence, the rise of sea level has caused erosion and inundation that are threatening not only the island but also the livelihood of its inhabitants. Nunn (2012:149) argues that sea level rise has had a widespread effect over the past 200 years that is now coming to a catastrophic climax. He further raised a concern that the 
islands, especially low-lying atolls, may not survive this century (Nunn 2012:157). However, even though the land is at risk of disappearing, the people will never agree to leave their ancestral homelands. At the World Climate Change Conference in Paris in 2015, Kiribati President Anote Tong delivered a speech during the opening day indicating that his country is the most vulnerable to the impact of sea level rise - thus calling international attention to the urgent action needed to address climate change (Burson 2010:78). Nunn (2012:157-158) quotes the lamentation of the prime minister of Tuvalu, Apisiai Jeremiah, who stated that:

For a highly vulnerable country like Tuvalu, we cannot just sit back and watch our homeland slowly disappear ... time is running out fast. Climate change could well be the greatest challenge that humanity has ever known. I make a very strong plea to all to act quickly and responsibly, to ensure that countries like Tuvalu do not disappear.

In addition, the author refers to the claim of Pacific island leaders that 'climate change remains the single greatest threat to the livelihoods, security and well-being of the peoples of the Pacific' (Nunn 2012:158). The voices of leaders in these most vulnerable countries have given stark warning about the end of the small Pacific islands (Nunn 2012:165). Storey and Hunter have not only attributed the issues of climate change to sea-level rise and inundation but also to anthropogenic activities of the inhabitants of the low-lying atoll islands such as unmanaged urbanisation, continued inadequate sanitation, lack of solid waste disposal controls and freshwater management (Storey \& Hunter 2010:198). It is noted that the changing landscape in Kiribati constitutes a critical part of the climate change problems that it is facing. Biribo and Woodroffe support this perspective that the widespread erosion around the islands is not only the impact of sea level rise but also the consequences that have been created by human activities of reclamation by building seawalls and causeways and taking soils and stones from the coastal areas for construction. This is especially the case in the capital island of Tarawa, which is the commercial capital (Biribo \& Woodroffe 2013:346). The contributions of Biribo and Woodroffe are helpful in creating awareness of climate change impact and the symptoms of environmentally destructive human activities; however, their contributions did not put much emphasis on any clear suggestion of how to inform people how to live in solidarity with their environment. These scholars did not dwell enough on how people could be informed and transformed contextually and culturally to become resilient communities and how they could be part of sustainability developments.

\section{People's notion of the coconut tree}

Havea (1987:293-298) is concerned that people are limited in their understanding to see God in the gift of creation that sustains and blesses them. He raises the need of contextual theology to share the gift of the coconut tree that speaks about the fullness of life that God has provided through Jesus. According to Havea, God exists in the lives of the people through their cultures, lands and context
(1987, 293-298). Having given the background introduction of a coconut tree theology, it is imperative to use the coconut tree to examine the coconut theology of life from Kiribati's perspective - how the people of the Kiribati understand God through the importance and use of the coconut tree in their context and culture.

\section{Presence of God}

The concept of the coconut plant is not just a physical plant, but it is a theology of life. It is almost like an earthly presence of God of life. In human form, Jesus is the embodiment of the presence of God in the world. In the environmental life, the coconut tree embraces a sign of the God who sustains life in the Kiribati. The Kiribati culture is embedded in the coconut tree as a symbol of their indigenous creation spirituality. In their world view, the divine presence of God is present in all creation. Therefore, the coconut tree constitutes a panentheistic construct of God's incarnational presence. When they celebrate, dance, eat, sleep, pray and even fight, the coconut tree viewed as a metaphor and image of God's presence tells the story of their life journey. Rev. Nakara Alisi (interviewed at Kiribati Presbyterian Church - KPC office, 30 September 2016) elaborates that:

'When it grows on coastal areas, it represents God's ecoresponsibility to protect the land. When it bears fruits, it speaks about the life-giving God who never sleeps but is always available to provide what is needed by those who rely on him. When it provides shelter, it speaks about God as the only refuge for security and protection. When it provides medicine, it speaks about God as saviour who has come to bring healings and wholeness to life that has been tortured by sinful desires of human greediness and selfishness.'

Even though the people of Kiribati are struggling to survive in the midst of climate change impacts, the coconut tree stands strong as a life-message pointing to the God who is not out there in heaven but exists among them. The coconut tree that they depend on for their survival always reminds the people of their cultural way of living as the only place to understand the meaning of life. In this regard, people need to live with the contextual understanding of God's involvement in their world; otherwise, they will live without appreciation and caring for the environment that provides them abundantly with all sources of life. According to Rev. Alisi (interviewed at KPC office, 30 September 2016), a respondent from the capital, Tarawa:

'In our coral islands, God has provided us with cultural trees that had sustained us and our forefathers for many generations such as breadfruit and te beero and even coconuts are quickly gone. Our way of life in our homes is changing rapidly and hence our culture. For our food, we have to rely now on imported goods and overseas products which is making us even more vulnerable to exogenous shocks. Life is now becoming more difficult than before. We have to limit visitors and family visitation and try to avoid cultural ceremonies, which can be very expensive.'

Tabe indicates that as life is changing, people should be stabilised culturally to avoid the influence of Western cultures 
that lead people to avoid their cultural ways of living and adopt modern culture, which is enslaved and controlled by money (interviewed at KPC office, 30 September 2016). Pastor Metutera Ale, (interviewed at Aranuka Kiribati, 20 July 2016) insists that 'we need to preserve the life of the coconut tree not because we are benefited from it physically but because we are also benefited from it spiritually'. He further argues that:
'... our understanding of God through the coconut tree is a powerful voice that reminds us of our ecological responsibility of care to all creation. It means therefore that when we destroy the life of the coconut tree, at the same time we will also destroy the God of life who has revealed himself as a life-giving God through the coconut tree.'

There is a sense in which the coconut functions as an idiom through which to interpret the presence of the present God in Jesus, who struggles for the liberation of the marginalised and all creation. The Gospel of Matthew embeds the story of Jesus as Immanuel, God with us, within the historical and political framework of the Roman regime with its colonisation and oppression of the Jewish people. The presence of God through Jesus Christ heralds the liberation and justice of God. The struggle for liberation and justice was evident through those who recognised and accepted Jesus as the presence of God in human form. The Kiribati people recognise the presence of a present God through the coconut tree and this gives them impetus to struggle for liberation and against climate injustice.

\section{The source of life}

The place of the coconut tree within the cosmos gives design to the life and culture of the people in Kiribati as coconut trees cover the landscape on each island and became the major contributors to sources of life. From the perspective of the I-Kiribati (the Kiribati people and nation) there is no other source of life that people rely on beside the coconut trees, which serves almost every need for the people - source of income, food, shelter, medicine and many other domestic needs (interview with Ribanataake Awira, Suva Fiji, 23 July 2016). Awira elaborates more on the value of this plant:

'The coconut tree has been a vital factor in the development of Kiribati as we know it today. This is the 'tree of life', providing a range of coconut flesh at different stages of development, drink, copra for export, wood for many uses, fronds for weaving, fibre for making string and even the basis of an alcoholic drink.' (Interview at Suva Fiji, 23 July 2016)

In this context, the green colour of the islands, reflected by the coconut palm trees, is a sign of God's hovering care and blessings over the land and the community of living things on the islands. The many elements of the coconut tree that satisfy the hunger and thirst of the people from the past until today is a reflection of the ever-present mission of God enfolded in an endless love and care in the culture and context of the people (interview with Teriba Tabe, Betty Trading, Banraeaba, 22 July 2016).
Particularly through its architectural structure, everything in a church building is symbolic of the coconut tree and reflects its place in cosmology. To a great extent in the Pacific, but especially in Kiribati, there is a strong link and identification between the church as a building and the coconut tree. That is why the coconut tree is one of the significant symbols in the emblem of the church. The building and church are to a certain extent a living cosmology of the tree (interview with Tabotabo Auatabu, Betio Tarawa, 21 November 2016). In addition, a particular beauty of the tree, apart from its cosmological associations, is that it is a renewable resource. The fact that it is renewable means it renews itself with new plants springing from the nuts. When a building made from the tree grows old or weak it can be easily replaced.

Therefore, the theological college that was built to equip pastors for relevant contextual engagement in ministry and mission must appropriate the theological significance of the coconut and use it as an indigenous knowledge system to make theological education relevant to meeting the challenges of climate change within the nation. The cosmology of the coconut tree is a living message of life in the Christian journey that needs to be renewed at all times, because the strength of the church is renewable. The coconut can travel with people when they move from island to island; it never sinks but puts out new seedlings when it comes to land (interview with Dr Matakite Tebana, Suva Fiji, 14 August 2016). According to Tebana:

'The cosmology of the traveling coconut points to the symbol of the church to be on the move with life despite the stormy sea and to reach island across distances dispersed in a wide ocean with the message of hope. The church never sinks in the midst of the rough and angry waves. The church should be a floating coconut with life in it, in the context of climate change and future uncertainty.' (Interview with Dr. Matakite Tebana, Suva Fiji, 14 August 2016)

The coconut tree not only helps people physically but also spiritually. The leaves and coconut oils are holy elements when people are connecting to their gods. The coconut tree is a medium that provides holy elements to facilitate people in worshiping their gods (interview with Tabotabo Auatabu, Betio Tarawa Suva Fiji, 21 November 2016). Within the traditional world view of the Kiribati people, their religion was polytheistic before the arrival of Western monotheistic Christianity. The process of inculturation over the centuries meant syncretistic fusion happened, in which the coconut tree was an important element in their faith formation and became a lens through which they sought to understand the key components of the Christian faith.

In Christianity, the coconut serves to provide holy elements for the body and blood of Jesus; as Havea (1987) says, bread and wine are not grown in the Pacific - they are foreign to us and very expensive to buy:

Bread is made from wheat and wine from grapes. The coconut is more relevant when it is recalled that the blood and flesh of Christ come from the one body. The coconut, its juice and meat are in the one same nut. (p. 298) 
Therefore, coconut tree theology as missiocultural element serves to connect the church with the indigenous culture that was destroyed by early missionaries. It serves to guide the church to see that in their island and context God is there with them - a God who is part of the culture and the context where the people live.

\section{Symbol of God's care}

The argument that God's love is reflected through the islands and their material well-being is widely discussed in the writings of Pacific theologians such as Havea. God and nature are closely linked in the world view. Tauma points to the coconut tree as one of the sources that provide the full meaning of what life is for an I-Kiribati. The flourishing coconut tree in the poor coral soil of Kiribati is a symbol of the church to stand strong and to flourish in the environment of uncertainty and hopelessness (interview with Rev. Taateti Tauma, Tangintebu Tarawa, 03 September 2016). Thus, TTC is challenged to provide a curriculum that is sustaining to the environment. The curriculum should transform the mission of the church to become a caring and serving church - a church that serves as a strong refuge that never sleeps but is always available to provide answers to what its members need at all times and in every circumstance that they are facing.

It is through the coconut tree that sustains life that we are always reminded to be sensitive of how we live sustainably and responsibly for our planet and for the glory of our God (interview with Raweai Teaioro, Bikenteriki Betio, 25 July 2016). Unfortunately, in the contemporary world, the value of the coconut tree in island culture is reduced and even ignored. For that reason, the cosmology of the tree is being forgotten. Today's island culture is an imported one, influenced by globalisation across the whole world. However, the coconut tree still flourishes on every island, reminding people of the existing God among the people and Christian theology. Mairara observed that even though our lives involve various influences that challenge us, changing our cultures and ways of living, the coconut tree stands strong as a living message showing us the way to respond to these changes (Mairara 2007:193). According to Palu, God exists in the lives of the people through their cultures, lands and context, so the coconut tree is very important to remind people of their culture and their religion in a changing world (Palu 2012:68).

It is essential that people see God in the world around them - not just in a future life but also in the here and now, and it is the role of the church to ensure people do realise this. As Kaunda and Hewitt (2015:378-392) observe, theological education is supposed to be a platform to initiate the shaping of the nation through its teachings, and these teachings must respond appropriately to the context and life experiences of the people. This is why the coconut tree and coconut theology are so important in the life of all I-Kiribati.

\section{Proposing a coconut theological praxis for Tangintebu Theological College theological education}

The coconut tree, which grows well in the coral islands of Kiribati, is a living message to the theological college to be a strong foundation and platform to support the lives of the people in every situation they are facing. It is a strong and fruitful tree, in the poorest soil, to inform theological education to be a life-giving institution to the urgent challenges of climate change within the Kiribati context. It is a life-giving tree informing TTC to revisit its curriculum to ensure theological and missional formation is designed to make ministerial students into leaders who are well equipped to effectively serve the island communities in any situation they are facing. Even though climate change is the greatest threat to life in Kiribati, the theological college will always stand strong as a stronghold of relevant resources and curriculum to equip ministers to provide relevant answers and hope in the current context of confusion and hopelessness. Like the coconut tree, theological education that seeks to appropriate the significance of the plant must therefore offer the people (1) life-giving and life-affirming resources. Such resources must speak to all areas of life in seeking to meet the people's needs. (2) The resources must be creation carecentred, ensuring that people live right with the environment (interview with Raweai Teaioro, Bikenteriki Betio, 25 July 2016).

The inclusiveness role of the coconut tree as provider of all needs of the people, homes for birds and insects and as protector of the environment and land on coastal areas is a living message to TTC about the inclusiveness of God's mission that needs to be considered in its theological curriculum. To be inclusive in their ministry, pastors should be equipped academically and practically within the cultural milieu of the Kiribati people (interview with Tabotabo Auatabu, Betio Tarawa, 21 November 2016). As McFague (2001) argues, the traditional story of God's incarnation in Christ tends to be presented as an anthropocentric mission. However, this is far from the holistic nature of the gospel of Christ. For De Gruchy (2010:42), the first praxis is 'an orientation toward the world' that points to God who is at work in the world (rather than just the church). Therefore, the missio Dei is one that encompasses all of creation. It is not the purpose of the church to be dominant in the curriculum, but the dominant factor should be that the purpose of God is alive in the world and followed by the curriculum. Indeed, in the indigenous knowledge of the Kiribati people, salvation is a holistic experience that involves all of creation.

Adding to this argument, Maeland (2016) expresses that there is a need for theological students to be well equipped culturally and theologically because the gospel and the people's way of life (culture) are interconnected. In the contemporary context of the people, the church must be prepared to embrace and offer good cooperation with people of cultures as 'life-affirming spirits present in different 
cultures' (Maeland 2016:555). The dominant role of the coconut tree in the islands of Kiribati is like an empire that aims for the common good of all. It stands as an inclusive challenge to the church, not to exist on its own but to exist to follow and respond to the missio Dei - the mission of God that continues to bring healing based on God's intimate relationship with all creation. Therefore, TTC must always consider how to reach out with the word of God to bring healing, hope and life in its fullness to creation. It is within the reign of God where the KUC and TTC should be extended in their mission beyond the boundary of the institutional church, caring and embracing the whole of God's creation. 'Faith traditions sustain reflections of our place in nature and what constitutes the proper goals of society and an individual life' (PCC Report 2007:174). Emerging from this, we suggest the following contours of coconut theological praxis to inform TTC theological education and ministerial formation.

\section{Eco-relationality}

One of the key arguments that emerged from the qualitative interviews was the theme of ecological relationality of all creation. This is confirmed in the response of Pacific ecotheologian Palu (2018) in his response to a paper delivered by Mutale Mulenga-Kaunda at the Conference on World Mission and Evangelism held at Arusha in Tanzania in March 2018. He argued that spiritual transformation cannot exist alone but must integrate with the social, economic and political transformation and action that responds positively to the felt needs of people. Palu (2018) points out the problems of 'the economy of one' in which the church shares, where the neoliberal economic narrative has given rise to inequalities and the growing desire for personal gains. It has led to a rise in negative relationships, which have even affected the church. Palu (2018) then raises a crucial question - when the church talks about 'fullness of life for all', who is 'all'? Bird says that the land is a symbol of the fullness of life, because it is where both human subsistence living and knowledge originated from. For this reason, humanity and ecology cannot be separated (Bird 2016:518). Palu (2018) points out that the church for centuries has used the phrase 'fullness of life' only to refer to people and that ecology refers only to the environment. Thus, the two notions seem to be separated and have given rise to the phrase 'eco-theology'. Palu (2018) believes that this conception of reality justifies people in developing economies that wreck everything around them. Palu's argument is that this breakdown in relationships between the two entities has helped to give rise to gender inequality and economic injustices. He therefore points out that ' $[a] 11$ of us are meant to exist in an eco-relational household', where harmony of life is upheld and resources are meant to be shared. In such a household, despite being different in race, gender and identity we are all diversely connected through an 'ecological reference'. He says we are all connected to the world around us and to God, through eco-relationality, giving rise to what is called 'relational ecumenism' (Palu 2018).
In relational ecumenism, the Spirit is central, more specifically, the Spirit's role in mission. ${ }^{1}$ Disciples are drawn into the world around us; we are part of this, not outside it. When we become disciples 'moved by the Spirit', we enter into a life of activity to sustain 'the economy of life' (Pavel \& Buda 2018). Kaunda (2017:37) calls capitalism 'a vampire research approach feeding on the ever-changing landscape of knowledge production, science, and technology' and even refers to a 'vampire world view' that exploits the marginalised and delivers more and more power into the hands of the Western researchers. 'We live in a world where everything is commercialized, from human trafficking to traditional knowledge' (Kaunda 2017:37).

In practical terms, Palu argues that because rationality was not part of policies and economic frameworks, because colonialism took everything without giving anything back, Pacific women became the victims of social and economic developments. In the Pacific indigenous world view, the land and ocean are closely interwoven with the people; women reflect ecorelationality (Palu 2018). The Kiribati world view shows sensitivity to the inclusiveness of humanity, their ancestors and every creature in the land. When family members die, they are buried in the home to connote their relationship with their families in the spiritual world, as they are still part of them (interview with Tessie Lambourne, Office of the President, Bairiki Tarawa, 08 July 2016). Therefore, damage done to the environment both damages the interconnectedness of the whole and leads to the slow death of vulnerable communities.

Palu went beyond what Mulenga-Kaunda had proposed, which was a radical mission formation for disciples, and suggests the church must not concentrate its theology of mission on people only but also must critique what he classifies as an 'economy of one'. He believes that this is at the heart of ecological destruction, and to restore ecorelationality and harmony for the 'fullness of life for all', the church must resist individualistic economic theory (Palu 2018). This theory argues that the greatest challenge for Pacific churches today is to produce an eco-relational theology of mission that is Spirit-driven. It must be able to promote the 'economy of life' and fight the 'economy of one' by fighting poverty and ecological annihilation and by becoming transformative. This approach to theological education and ministerial formation is crucial if TTC is to be relevant in the context of climate change. Theological education and ministerial formation cannot be business as usual. It has to engage the changing climate landscape in which the Kiribati people are living.

\section{Missio-culturality}

Even though the Pacific islands, especially Kiribati, are enduring the greatest threat of islands sinking because of sealevel rise, the coconut tree provides resources to facilitate the production of an eco-relational theology of mission that points to the source of this life as God through the Spirit:

1.For a detailed discussion on the relationship between the Holy Spirit and mission, see the edited volume on Ecumenical Missiology by Ross et al. (eds. 2016). 
One that is able to link the suffering of the vulnerable to poverty and ecological annihilation, and that is transformative and subversive to promote the 'economy of life' that is Spirit driven. (Palu 2018)

Conradie observed that, for a moral formation, it is a challenge to Christians to proclaim the word of God at a time when it is most needed, where it hurts most (Conradie 2009:40). As participants argue, the coconut theology communicates and embodies a mission cultural lens through which to understand theological education and ministerial formation at TTC. Tangintebu Theological College is challenged to be more eco-missional in its curriculum if it aims to conscientise its students regarding their land and environment.

Missio-culturality points to the value of indigenous culture and knowledge in teaching theological education and ministerial formation. It challenges TTC to incorporate in its curriculum coconut perspectives and become more practical and meaningful in the context of climate change. The coconut theology as mission-cultural theory used in this study is to help the church to focus more on the lives and contemporary context of the people. It assists to provide the notion of the intimate existence of the living God, who continues to provide life to the people in whatever context people are living and in whatever crisis they are going through. This theory calls the people of Kiribati to acknowledge the presence of God in their way of life in order to be part of the ongoing mission of God in their context.

This argument has affinity with Conradie's view of earthkeeping in which he links issues of climate change and environmental degradation to theological education and the mission of the church. Eco-missional earthkeeping ethics seeks to address the contemporary challenges and points out that salvation must be explored; not only on the resurrection and the cross but on the life, parable wisdom and suffering of Christ (Conradie 2009:48). Coconut theology as communicating with God is employed as an eco-missional lens to challenge TTC to be more ecomissional in its curriculum, to transform society, which has been ignorant regarding their land and environment. In fact, Conradie's root metaphor of the household of God indicates a deep relationship between ecclesiology and ecology in the world - the household of God (2016:6). Conradie asserts that the household of God is controlled by the rule by which the house is managed, and it is to be treated according to how the household is structured, by humans and other forms of life. The world may be 'redescribed as God's household while God's economy, God's acts of house-holding, include not only God's work of creation, salvation, and consummation, but also the formation, up-building governance, ministries, and missions of the church' (Conradie \& Ayre 2016:7). Although speaking from a South African context, Conradie's use of the term 'earthkeeping' speaks aptly to the Kiribiti notion of an eco-relationality world view in which the whole of creation must work in unity to sustain all of life. Therefore, coconut theology as missio-culturality challenges TTC to explore together, using a culturally informed language in the process of equipping theological students for climate change.

\section{Conclusion}

The article argues that the church should not be silent and inactive in the crisis facing the lives of the people and that this needs urgent response. It proposes that the TTC model of theological education and ministerial formation must be revised within the Kiribati cultural imagination in order to make sense in the contemporary context of climate change. Based on qualitative interviews, the article demonstrated that the church must be vocal against issues of injustice that are suppressing and destroying creation and the people.

Tangintebu Theological College has a responsibility to the missio-cultural context of its students. This means that TTC should be sensitive to cultural values and indigenous knowledge in the process of equipping student in the Kiribati islands. According to Maeland (2016:551-563), theological students need to be well equipped culturally and theologically because these two aspects are inseparable in the process of critical appropriation of the gospel. Where fullness of life is lacking, there mission must act, because God is not bound by the presumed boundaries of the church, so the church should not be so bound either. Therefore, the challenge for TTC is to take a conscious and intentional approach to relate the Christian faith to the Kiribati cultural context in order to respond adequately to the crisis of climate change.

The article argues for the significance of understanding Christian faith through the medium of the coconut trees, which people perceive as the presence of a present God among the Kiribati people. The presence of a present God must be related to climate change, which shows itself through the rising sea levels and the consequences of contaminated groundwater and eroded beaches. The ever-presence of the coconut trees in the midst of climate change give hope to the local people, who symbolically say, 'Here he is; he has not forgotten you'. While the trees stand tall, God is there with the people. However, the God of life and justice symbolised by the coconut tree only acts through those who recognise and acknowledge his divine presence. In other words, God's vision for theological education and ministerial formation at the locus of enunciating not only right action, but also just action, to respond to the injustice and exploitation contributing to climate change. The coconut trees that cover the islands remind the people that God will never turn his back on them.

\section{Acknowledgements Competing interests}

The authors declare that they have no financial or personal relationships that may have inappropriately influenced them in writing this article. 


\section{Authors' contributions}

T.T. was the project leader and was responsible for methodology, formal analysis, fieldwork, writing-original draft preparation, and writing-review and editing. C.J.K. did most of the conceptualisation, methodological development, theory, formal analysis, writing-original draft preparation, and writing-review and editing. R.R.H. did some of the formal analysis and writing-review and editing.

\section{References}

Bird, C., 2016, 'Together towards life and contemporary pacific theology,' in K.R. Ross, J. Keum, K. Avtzi \& R.R. Hewitt (eds.), Changing landscapes and new conceptions of mission, pp. 507-518, Regnum Edinburgh Centenary, Oxford.

Biribo, N. \& Woodroffe, C.D., 2013, 'Historical area and shoreline change of ree islands around Tarawa Atoll, Kiribati',' Sustainability Science 8(3), 345-362. https://doi.org/10.1007/s11625-013-0210-z

Burson, B. (ed.), 2010, Climate change and migration: South Pacific perspectives, Institute of Policy Studies, Wellington.

Collins, P., 2012, 'Climate view from a nation doomed to drown', Eureka Street 22(24), 31-32.

Conradie, E.M., 2009, 'Theological resources for responding to climate change: An overview. Missionalia', Southern African Journal of Mission Studies 37(1), An overvir
$33-52$.

Conradie, E.M. \& Ayre, C.W., 2016, 'Ecclesiology and ecology in ecumenical perspective', in C.W. Ayre \& E.M. Conradie (eds.), The Church in God's Household: perspective, in C.W. Ayre \& E.M. Conradie (eds.), The Church in God's Household:
Protestant perspectives on ecclesiology and ecology, pp. 1-9, Cluster Publications, Protestant perspectiv
Pietermaritzburg.

De Gruchy, S., 2010, 'Theological education and the Mission of the Church', in D. Werner, D. Esterline, N. Kang \& J. Raja (eds.), Theological education in World Christianity, pp. 42-49, WIPF \& Stock Publishers, Eugene.

Donner, S.D. \& Webber, S., 2013, 'Obstacles to climate change adaptation decisions: A case study of sea-level rise and coastal protection measures in Kiribati', Sustainability Science 9(3), 331-345.

Forman, C.W., 2005, 'Finding our own voice: The reinterpreting of Christianity by oceanian theologians', International Bulletin of Missionary Research 29(3), 115-122. https://doi.org/10.1177/239693930502900301

Gittins, A.J., 1999, 'Kiribatizing Christianity: A Local Church Rediscovers Itself', Mission Studies 16(2), 71-99.

Havea, J., 1987, 'Pacific Christianity and people solidarity', The Journal of the I.T.C. 16(1-2), 293-298.

Kaunda, C.J., 2017, 'On the road to Emmaus: Together towards life as conversation partner in missiological research', International Review of Mission 106(1), 34-50. https://doi.org/10.1111/irom.12162

Kaunda, C.J., 2018, 'The Nation That Fears God Prospers': A Zambian Pentecostal Theology of Nations, Fortress (forthcoming), Minneapolis, MN.
Kaunda, C.J. \& Hewitt, R.R., 2015, 'Toward epistemic decolonial turn in MissioFormation in African Christianity', International Review of Mission 104(2), 378-392. https://doi.org/10.1111/irom.12110

Kiribati National Statistic Office, 2016, Population and Housing Census, National Statistics Office, Ministry of Finance, Tarawa, Kiribati.

Loughry, M. \& McAdam, J., 2008, 'Kiribati-relocation and adaptation', Forced Migration Review 31(2), 51-52.

Maeland, B., 2016, 'Together towards life and the challenge of Missional Formation', Ecumenical Missiology: Changing landscapes and new conceptions of mission, in K.R. Ross, J. Keum, K. Avtzi \& R.R. Hewitt (eds.), Changing landscapes and new conceptions of mission, pp. 551-563, Regnum Edinburgh Centenary, Oxford.

Mairara, J., 2007, 'The floating coconut: A contextual approach to methodist mission in Fiji's Context', Asia Journal of Theology 21(2), 183-196.

McFague, S., 2001, Life abundant: Re-thinking theology and economy a planet in Peril, Fortress Press, Minneapolis, MN.

Nunn, P.D., 2012, 'The end of the Pacific? Effect of the sea level rise on Pacific islands Livelihood', Singapore Journal of Tropical Geography 134(2), 143-171. https://doi. org/10.1111/sjtg.12021

Palu, M., 2012, 'Dr Sione Amanaki Havea of Tonga: The architect of pacific theology', Melanesian Journal of Theology 28(2), 67-81.

Palu, M., 2018, 'A brief response to 'Transforming Disciples, Transforming the future: Young African women and the search for a liberated future' by Mutale MulengaKaunda', Conference on World Mission and Evangelism, 8-13 March 2018, Arusha Tanzania, pp. 1-4

Pavel, A. \& Buda, D., 2018, 'Moving in the spirit: Called to transforming discipleship: Conference on World Mission and Evangelism, 8-13 March, 2018, Arusha, Tanzania', RES 10(1), pp. 106-111.

PCC Report, 2007, Report of the Ninth Assembly of the Pacific Conference of Churches, Kananafou, American Samoa 02-08 September, 2007, The Pacific Conference of Churches, Fiji.

Ross, R.K., Keum, J., Avtzi, K. \& Hewitt, R.R. (eds.), 2016, 'Ecumenical Missiology', in Changing landscapes and new conceptions of mission, Regnum Edinburgh Centenary, Oxford.

Storey, D. \& Hunter, S., 2010, 'Kiribati: An environmental perfect storm', Australian Geographer 41(2), 167-181. https://doi.org/10.1080/00049181003742294

Tenten, R., 1994, 'A technological Dilemma in Kiribati and a Missiological Response', BD thesis, Pacific Theological College, Fiji.

Thaman, R.R., 1990, 'Kiribati agroforestry: Trees, people and the Atoll Environment', Atoll Research Bulletin 333, 1-29. https://doi.org/10.5479/si.00775630.333.1

Thomas, F., 2002, 'Self-Reliance in Kiribati: Contrasting views of agricultural and fisheries production', The Geographical Journal 168(2), 163-177. https://doi. org/10.1111/1475-4959.00045

Tielu, A.J., 2016, 'Searching for the Digital Fāgogo: A study of indigenous samoan storytelling in contemporary Aotearoa Digital Media', Unpublished PhD Thesis, Auckland University of Technology, New Zealand.

Timon, T., 2013, 'A theological reflection of land in the context of climate', Unpublished M.Th Thesis, Charles Stuart University, Sydney.

Uriam, K., 1999, 'Theology and practice in the Islands: Christianity and Island Communities in the New Pacific, 1947-1997', Unpublished PhD Thesis, Australian National University, Canberra.

Walliman, N., 2011, Research methods: The Basics, Routledge, London. 